\title{
SÚMULA VINCULANTE E PROTEÇÃO DOS DIREITOS FUNDAMENTAIS
}

\author{
ANTONIO MOREIRA MAUÉS*
}

\begin{abstract}
RESUMO: A partir da interpretação das normas constitucionais sobre a edição de súmulas vinculantes, o artigo analisa o modo como o Supremo Tribunal Federal vem exercendo sua competência nessa matéria e suas conseqüências para a proteção dos direitos fundamentais no ordenamento jurídico brasileiro.

PALAVRAS-CHAVE: Súmula Vinculante; Direitos Fundamentais; Supremo Tribunal Federal; Direito Constitucional Brasileiro.
\end{abstract}

ABSTRACT: Based on the interpretation of constitutional rules about binding precedents, the article analyses the ways the Federal Supreme Court exercises its power in this field and its consequences to the protection of constitutional rights in Brazilian legal system. KEYWORDS: Binding Precedent; Constitutional Rights; Federal Supreme Court; Brazilian Constitutional Law.

SUMÁRIO: 1. Duas idéias e dois modelos; 2. As Súmulas Vinculantes na Constituição: "reiteradas decisões" e "questão idêntica”; 3. As Súmulas Vinculantes no Supremo Tribunal Federal; 4. Conclusão; 5. Referências Bibliográficas.

SUMMARY: 1. Two ideas and two models; 2 . The binding precedents in the Constitution: "reiterated decisions" and "identical matters"; 3 . The binding precedents in the Supreme Federal Court; 4. Conclusion; 5. Bibliographical References.

\section{DUAS IDÉIAS E DOIS MODELOS}

No decorrer do século XX, a proteção judicial da Constituição consolidou-se como um importante mecanismo de defesa do Estado Constitucional. No continente americano, apesar da experiência do judicial review ter inspirado o constitucionalismo de diversos países desde o século anterior, os períodos autoritários limitaram o desenvolvimento da justiça constitucional, que passou a cumprir um papel de destaque com as novas constituições democráticas aprovadas nas últimas décadas (Brasil, Colômbia). Na Europa, após as primeiras tentativas de implantação da justiça constitucional no período entre-guerras (Tchecoslováquia, Áustria e Espanha), a segunda metade do século presenciou três ondas de expansão dos tribunais constitucionais, que acompanharam o surgimento de Estados democráticos após o fim de regimes fascistas (Alemanha, Itália), de regimes autoritários de direita (Portugal, Espanha) e de regimes autoritários de esquerda (Pacto de Varsóvia).

Artigo recebido em 08.07.2009 e aprovado para publicação pelo Conselho Editorial em 14.10.2009.

* Professor Associado da Universidade Federal do Pará; Doutor em Direito pela Universidade de São Paulo; Pesquisador do CNPq. 
A expansão da justiça constitucional tornou a divisão “pura” entre sistemas difuso e concentrado incapaz de dar conta da diversidade de experiências existentes (PEGORARO, 2004). No entanto, as possibilidades de desenvolvimento e aproximação dos dois modelos clássicos estão limitadas pelos princípios e objetivos que os regem, o que torna indispensável o conhecimento dos fundamentos teóricos da justiça constitucional para que se possa compreender suas características institucionais (LLORENTE, 1997, p. 467). O exame desses fundamentos demonstra que o modelo "americano" e o modelo "europeu” atendem a idéias distintas de Constituição e justiça constitucional.

Na experiência norte-americana, a defesa padrão do judicial review é o artigo federalista $n^{\circ} 78$, escrito por Alexander Hamilton. No conjunto da obra, esse texto encerra a exposição sobre a divisão de poderes adotada pela Constituição, tratando ainda da organização e das competências da judicatura federal. Nele, a tradição de independência judicial da common law aparece como um pressuposto da atribuição aos juízes do poder de fiscalizar as decisões do legislador.

Em primeiro lugar, Hamilton (1984, p. 576-580) argumenta em favor da vitaliciedade dos magistrados, considerada necessária para garantir a independência do judiciário em relação aos demais poderes e, consequentemente, possibilitar que ele exerça suas funções de controle. Essa independência seria especialmente valiosa diante do legislativo, tendo em vista que a Constituição norte-americana - supreme law of the land - fora concebida como uma "Constituição limitada”, contendo determinadas restrições ao legislador, tal como a vedação de confisco e de leis ex post facto. Limitações desse tipo só poderiam ser preservadas, na prática, por meio do poder judiciário, que teria o dever de declarar nulos todos os atos contrários à Constituição.

A atribuição dessa importante competência ao judiciário justifica-se, para Hamilton, em razão da interpretação das leis ser o campo de atuação próprio dos juízes, o que lhes permite desempenhar o papel de intermediários entre o povo e o legislativo. ${ }^{1}$ O judicial review, assim, aparece como a garantia da Constituição e dos direitos nela reconhecidos, impedindo sua violação pelo legislador e também protegendo os cidadãos contra leis injustas e parciais, por moderar seus malefícios ou dissuadir sua aprovação.

Mais de um século depois, Kelsen irá defender a garantia jurisdicional da Constituição a partir de um outro conjunto de idéias. O problema central, para Kelsen, é a busca de garantias do exercício regular das funções estatais, de acordo com sua concepção da estrutura hierárquica da ordem jurídica. Assim, os instrumentos de controle já existentes no campo da execução da lei, deveriam ser expandidos para o campo da legislação: "Garantias da Constituição significam, portanto, garantias da

\footnotetext{
1 “Uma Constituição é, de fato, a lei básica e como tal deve ser considerada pelos juízes. Em conseqüência cabe-lhes interpretar seus dispositivos, assim como o significado de quaisquer resoluções do Legislativo. Se acontecer uma irreconciliável discrepância entre estas, a que tiver maior hierarquia e validade deverá, naturalmente, ser a preferida; em outras palavras, a Constituição deve prevalecer sobre a lei ordinária, a intenção do povo sobre a de seus agentes” (HAMILTON, 1984, p. 578).
} 
regularidade das regras imediatamente subordinadas à Constituição, isto é, essencialmente, garantias da constitucionalidade das leis” (KELSEN, 2003, p. 126).

Baseando-se na concepção de que a Constituição é norma sobre a produção de normas gerais, o modelo kelseniano não reserva nenhum papel importante na justiça constitucional para a proteção dos direitos fundamentais, ${ }^{2}$ tal como se verifica nas seguintes teses:

a) a inconstitucionalidade material é, em última análise, inconstitucionalidade formal, pois uma lei cujo conteúdo contraria a Constituição deixaria de ser inconstitucional se fosse aprovada como emenda à Constituição (KELSEN, 2003, p. 132);

b) a centralização do controle de constitucionalidade justifica-se em nome da segurança jurídica, mesmo que isso limite o papel do judiciário na proteção de direitos (KELSEN, 2003, p. 144-145);

c) atos jurídicos individuais não são, em regra, objeto de controle (KELSEN, 2003, p. 161);

d) as decisões de inconstitucionalidade não possuem efeito retroativo (KELSEN, 2003, p. 171);

e) os cidadãos não dispõem de acesso direto à jurisdição constitucional (KELSEN, 2003, p. 174-175);

f) a justiça constitucional é especialmente necessária nos Estados Federais, a fim de manter o equilíbrio das relações entre governo central e governos estaduais (KELSEN, 2003, p. 182).

Os diferentes princípios que regem os dois modelos ajudam a entender seu distinto caráter difuso ou concentrado. No caso norte-americano, a posição do judiciário como defensor do cidadão contra o poder legislativo permite a qualquer indivíduo ameaçado por um ato legal buscar o remédio judicial. No caso europeu, a defesa da ordem constitucional de competências requer a criação de um tribunal ad hoc e a limitação da legitimidade ativa.

Por essa razão, apesar das aproximações entre o modelo americano e europeu de justiça constitucional (FAVOREU, 1988), algumas diferenças permanecem irredutíveis. No campo do controle concentrado, a busca de atender às demandas dos cidadãos levou à criação da via incidental e do recurso direto, de caráter subsidiário, ao tribunal constitucional. No entanto, no primeiro caso, a decisão final sobre a demanda depende do juiz ordinário, e não do tribunal constitucional; no segundo caso, as experiências alemã e espanhola mostram a constante tentativa de limitar o acesso à verfassungsbeschwerde e ao recurso de amparo, tendo em vista que o volume de ações tornou-se incompatível com a estrutura dos respectivos tribunais.

\footnotetext{
${ }^{2}$ De acordo com Llorente (1997, p. 475-476), os constituintes austríacos de 1920, que criaram o sistema concentrado de justiça constitucional, nunca chegaram a aceitar plenamente a idéia de que a Constituição é um corpo normativo do qual derivam, para todos os integrantes do corpo político, direitos e obrigações que os juízes devem proteger e fazer cumprir, inclusive frente ao legislador: "La Constitución obliga al legislador, pero no otorga a los ciudadanos, como correlato de esa obligación, derechos para los que éstos puedan pedir la tutela judicial; los derechos de los ciudadanos nacen sólo de la ley y sólo a la ley está sujeto el juez”.
} 
Já no campo do controle difuso, a busca de segurança jurídica levou à adoção de formas mistas, por meio da criação de um tribunal constitucional ou pela atribuição à Corte Suprema ou a uma de suas Salas da competência para julgar, por via direta, a constitucionalidade das leis. Contudo, a impossibilidade de restringir o acesso do cidadão ao judiciário deixa sem solução o problema da divergência jurisprudencial na interpretação da Constituição, demandando a criação de mecanismos de articulação entre a via direta e a via incidental.

O Brasil expressa, particularmente, os limites de cada um dos modelos, bem como as dificuldades de mesclar seus elementos para solucionar os problemas acima apontados. Tendo adotado o controle difuso juntamente com o regime republicano, já na Constituição de 1934 o país criou o instituto da resolução suspensiva do Senado Federal, para permitir a extensão dos efeitos da declaração de inconstitucionalidade. Em 1965, por meio da Emenda Constitucional $n^{0} 16$, implanta-se o controle concentrado, visando estabelecer um mecanismo mais ágil de fiscalização da constitucionalidade do direito estadual. Em 1988, mudança significativa ocorreu com a criação das ações diretas de inconstitucionalidade, cuja legitimidade ativa foi conferida a uma ampla gama de agentes, incluindo minorias políticas e entidades sociais.

Desde então, o desenvolvimento da justiça constitucional no país tem sido pautado pelos problemas decorrentes da convivência entre controle difuso e concentrado. Com a ampliação da legitimidade ativa nas ADIns e o incremento do exercício do controle difuso, a ausência de mecanismos de articulação entre os dois sistemas permitia julgar pela via incidental, diversas vezes, uma matéria sobre a qual o STF já se manifestara na via direta. Assim, tornou-se recorrente a divergência entre as decisões tomadas pelo STF e pelas demais instâncias do Judiciário, especialmente nos casos em que o Supremo Tribunal negava, em ADIn, o pedido cautelar de suspensão dos efeitos de uma norma, enquanto outros juízes declaravam-na inconstitucional no exercício do controle difuso. De modo semelhante, mesmo uma questão julgada repetidas vezes, em igual sentido, por meio de recurso extraordinário, poderia continuar recebendo decisões distintas dos demais juízes e tribunais.

Na busca de solucionar os problemas causados por essa divergência jurisprudencial sobre a interpretação da Constituição, foram adotadas as técnicas do efeito e da súmula vinculantes, que trouxeram um conjunto de conseqüências para o sistema (SCAFF; MAUÉS, 2005, p. 69-70):

a) o controle difuso e o controle concentrado passaram a se articular na direção do abstrato ao concreto, dado o efeito vinculante das decisões tomadas pelo STF na via direta sobre as decisões tomadas na via incidental;

b) a vinculação dos juízes à jurisprudência do STF deixou de ter um caráter meramente intelectual, baseado na força persuasiva de suas decisões, e passou a ter um caráter dissuasivo, no qual a não observância da jurisprudência acarreta a cassação de decisões por meio do instituto da reclamação;

c) o efeito e a súmula vinculantes caracterizam-se como mecanismos de prevenção da divergência sobre a interpretação constitucional, e não como mecanismos de correção. Eles visam que os juízes se adaptem às orientações jurisprudenciais do STF, 
evitando que as dúvidas sobre a constitucionalidade da lei cheguem ao Tribunal e dificultando uma nova análise da questão que ensejou a divergência.

Esse conjunto de mudanças parte de um diagnóstico em torno dos riscos que a incerteza e a demora dos pronunciamentos judiciais sobre determinada questão trazem para a segurança jurídica, apontando como solução a uniformização da jurisprudência constitucional na matéria, com base na orientação do STF. Apesar da validade dessa preocupação, as limitações que o novo modelo impõe ao exercício do controle difuso, ao vincular o juiz às decisões do STF, exigem uma reflexão sobre suas conseqüências para a proteção judicial dos direitos fundamentais. No campo do controle concentrado, a declaração de constitucionalidade da lei não exclui a possibilidade de que, quando de sua aplicação a casos concretos, possa haver violação de direitos fundamentais; ${ }^{3}$ no caso das súmulas, sua aplicação sem o conhecimento dos precedentes que levaram a sua edição, pode dificultar a identificação de circunstâncias do caso que autorizam não aplicá-la, a fim de preservar direitos das partes envolvidas.

Neste momento, portanto, vivemos uma disputa em torno da caracterização da justiça constitucional em nosso país. As técnicas do efeito e da súmula vinculantes inspiram-se em um modelo de justiça constitucional voltado para a preservação da segurança jurídica, o que explica as limitações à possibilidade do juiz afastar-se dos precedentes estabelecidos pelos tribunais superiores e o uso de mecanismos para dissuadir ou vedar a não aplicação do precedente. Do outro lado, a tradição do controle difuso e o amplo reconhecimento de direitos fundamentais em nossa Constituição inspiram-se em um modelo de justiça constitucional voltado para a proteção de direitos, o que exige reconhecer a possibilidade do juiz afastar-se do precedente, desde que o faça de modo fundamentado, apresentando argumentos que indiquem sua inaplicabilidade ao caso (MAUÉS, 2008). Em outras palavras, busca-se que a defesa da ordem constitucional não desloque para um plano secundário a proteção dos direitos fundamentais.

Nas seções seguintes deste trabalho, analisaremos como a prática das súmulas vinculantes se enquadra nesse contexto. A partir da interpretação das normas constitucionais sobre a matéria, buscaremos identificar de que modo o STF vem exercendo essa competência e suas conseqüências para a proteção dos direitos fundamentais em nosso ordenamento. ${ }^{4}$ Objetivamos, portanto, explorar o caminho que vem sendo seguido, para propor eventuais correções que se façam necessárias.

\section{AS SÚMULAS VINCULANTES NA CONSTITUIÇÃO: "REITERADAS DECISÕES” E “QUESTÃO IDÊNTICA”}

Durante o longo processo que levou à sua aprovação, as súmulas vinculantes foram defendidas em nome da segurança jurídica e criticadas com base no princípio do acesso à justiça. ${ }^{5}$ A seriedade das críticas quanto aos riscos que as súmulas trariam

\footnotetext{
${ }^{3}$ Para uma síntese desses casos, cf. Scaff; Maués (2005, p. 53-61).

${ }^{4}$ Neste trabalho, utilizou-se a página do STF na internet (www.stf.jus.br) para ter acesso à integra dos acórdãos citados.

${ }^{5}$ Para uma síntese, ver Mancuso (2005) e Medina; Wambier; Wambier (2005).
} 
ao livre convencimento do juiz, fez com que a EC no 45 estabelecesse um conjunto de critérios para sua edição, vinculando o exercício da competência do STF. Além de exigências de caráter procedimental, dentre as quais se destaca a maioria de dois terços para a aprovação de súmulas vinculantes, a Constituição impõe outros parâmetros, que dependem de um juízo de caráter substantivo: a existência de "reiteradas decisões sobre matéria constitucional" em que haja "controvérsia atual” que "acarrete grave insegurança jurídica e relevante multiplicação de processos sobre questão idêntica”.

Em comparação com o efeito vinculante das decisões tomadas pelo STF no controle concentrado, as súmulas teriam a vantagem de buscar a harmonização da jurisprudência constitucional a partir de casos concretos e não com base em um pretenso "juízo abstrato de constitucionalidade”, pouco favorável à identificação da violação de direitos em situações particulares. Como vemos, a existência de controvérsia e de grave insegurança jurídica não são suficientes para autorizar a edição de súmula, pois é necessário que haja similitude entre os casos que justifique tratá-los como “questão idêntica”, em torno da qual se pronunciam “reiteradas decisões”.

A identidade das questões que fundamentam a edição de súmulas não deve ser interpretada, contudo, como um dado natural, que caberia ao STF simplesmente reconhecer. Como qualquer proposição no campo do direito (DWORKIN, 1991, cap. 1), a afirmação de que uma questão é idêntica à outra não se baseia apenas em uma análise de circunstâncias de fato, ou seja, sobre a ocorrência ou não de determinados eventos físicos, mas especialmente nos critérios utilizados para qualificar juridicamente esses fatos. Mesmo que não haja divergência entre os julgadores sobre os aspectos factuais de uma demanda, ainda assim pode haver soluções díspares para ela, baseadas em diferentes interpretações dadas ao caso.

Dessa forma, a observância dos ditames constitucionais para edição de uma súmula vinculante depende de que o STF interprete corretamente um conjunto de casos como iguais, valorizando suas similitudes e desprezando suas diferenças. A afirmação da existência de decisões reiteradas se baseia no entendimento de que, apesar de suas particularidades, os casos devem ser julgados no mesmo sentido, assumindo que a interpretação dada a um deles também é válida como parâmetro de decisão em outros. Isso impõe que a análise das características dos casos julgados nos precedentes seja feita com muito cuidado, para que se possa afiançar que está correta a generalização de seus fundamentos.

Nota-se, portanto, que o processo de edição de súmulas vinculantes acentua a indissociabilidade entre os fundamentos da decisão e o caso, que se integram em um mesmo processo hermenêutico. Os fundamentos são elaborados nos precedentes de acordo com determinadas circunstâncias e só é possível saber se devemos resolver da mesma maneira casos futuros se conhecemos essas circunstâncias. Não cabe à súmula vinculante ir além dos fatos qualificados juridicamente nos precedentes, ultrapassando o contexto que permite a compreensão de seus fundamentos. Caso isso ocorra, deixa-se de atender às exigências constitucionais e dificulta-se a identificação, a partir de seu enunciado, das questões idênticas em relação às quais - e somente às quais - ela deve ser aplicada. 
Apesar de não ser possível à súmula conter todo o processo hermenêutico em que ela se baseou, seu enunciado deve buscar apresentar os fundamentos que se quer generalizar de modo contextualizado, referindo-se a elementos dos casos tratados nos precedentes. Essa formulação também é importante para o processo de aplicação da súmula vinculante, tendo em vista que a análise que o juiz deverá fazer, para decidir se cabe ou não sua aplicação em determinado caso, requer o conhecimento do modo como os fatos tratados nos precedentes foram interpretados pelo STF. Não se trata, aqui, de eliminar a abertura de sentido que, como qualquer texto, as súmulas conterão, mas de destacar que, quanto mais abstrato for o enunciado, maiores serão as dificuldades para identificar as similitudes dos precedentes com os casos atuais. Isso favorece um tipo de raciocínio subsuntivo na aplicação das súmulas, que, ao tratá-las como uma premissa maior e não como um objeto da interpretação jurídica (STRECK, 2005, p. 139) resulta em sua incorreta aplicação.

Assim como o STF realiza um juízo de igualdade para proferir reiteradas decisões sobre uma matéria, também o juiz (e o administrador), encarregado da aplicação da súmula a novos casos, deve examinar suas características para concluir se está diante de uma questão igual ou diferente. Atenta a essa necessidade, a própria EC $n^{0} 45$ estabeleceu duas hipóteses em que cabe reclamação ao STF por desrespeito à súmula vinculante: contra ato administrativo ou decisão judicial que a contraria, ou que indevidamente a aplica. No primeiro caso, o STF determinará que outra decisão seja proferida com aplicação da súmula; no segundo caso, que a nova decisão seja proferida sem aplicação da súmula.

Tal proceder também é exigido pela vinculação da jurisdição ao direito fundamental à igualdade, que impõe ao juiz um duplo dever: não discriminar as situações iguais, aplicando os precedentes, e discriminar as situações desiguais, deixando de aplicar os precedentes. ${ }^{6}$ A falha em cumprir com a primeira obrigação viola o direito a um tratamento igual, em que não devem ser consideradas as diferenças entre os sujeitos; a falha em cumprir com a segunda viola o direito a um tratamento desigual, em que devem ser levadas em consideração determinadas diferenças (MAUÉS, 2008, p. 94-95).

Veremos, na seção seguinte, como o STF tem lidado com essas exigências constitucionais.

\section{AS SÚMULAS VINCULANTES NO SUPREMO TRIBUNAL FEDERAL}

As súmulas vinculantes foram inauguradas com um enunciado que, expressamente, assumia a necessidade de análise das particularidades de cada caso para sua aplicação. ${ }^{7}$ Os precedentes trataram de recursos contra decisões tomadas pelas Turmas Recursais dos Juizados Especiais Federais do Rio de Janeiro, que julgavam inválidos os acordos firmados pelos trabalhadores com base na LC $n^{0} 110 / 2001$, questão

\footnotetext{
${ }^{6}$ Vale lembrar que, no direito norte-americano, o princípio do stare decisis exige o conhecimento dos fundamentos (ratio decidendi) das decisões anteriores, a fim de que se possa aferir se as características do caso justificam a aplicação do precedente ou demonstram sua inadequação (distinguishing). Cf. Miranda (2007).

${ }^{7} \mathrm{SV} \mathrm{n}{ }^{\circ}$ 1: "Ofende a garantia constitucional do ato jurídico perfeito a decisão que, sem ponderar as circunstâncias do caso concreto, desconsidera a validez e a eficácia de acordo constantes de termo de adesão instituído pela Lei Complementar nº 110/2001”.
} 
essa que havia sido, inclusive, sumulada pelas Turmas Recursais. ${ }^{8}$ Para o STF, não se podia aceitar o argumento de que houvera vício de consentimento da parte do trabalhador ao firmar o termo de adesão para a correção de contas do FGTS, pois tal situação deveria ser analisada acordo por acordo, e não de modo abstrato, como no Enunciado $n^{\circ}$ 21. Nota-se, assim, que o próprio STF critica no precedente a aplicação de um enunciado "abstrato", o que explica a ressalva feita na SV no 1 às circunstâncias do caso concreto, ou seja, a possibilidade de ocorrência de vício. A súmula, portanto, não proíbe que o judiciário examine a validade e eficácia desses acordos, mas exige que o faça analisando as características de cada caso.

As dificuldades para manter a súmula fiel às "reiteradas decisões” que devem antecedê-la não tardaram, contudo, a aparecer. Nos debates da SV n ${ }^{\circ} 3^{9}$, propôs-se que os atos de admissão de pessoal também fossem excluídos da obrigatoriedade do contraditório e da ampla defesa perante o Tribunal de Contas da União, ao lado dos atos de concessão inicial de aposentadoria, reforma e pensão. Apesar dos Ministros reconhecerem que o mesmo fundamento constitucional ${ }^{10}$ se aplicava a todos esses casos, a proposta foi recusada por não ter sido objeto dos precedentes.

De modo semelhante, na SV $n^{\circ} 6^{11}$ o debate se desenvolve em torno da inclusão ou não no enunciado das "praças especiais". Os precedentes trataram da constitucionalidade do art. $18, \S 2^{\circ}$ da $M P n^{\circ} 2.215-10 / 01$, que permite o pagamento de remuneração inferior ao salário mínimo tanto às praças prestadoras de serviço militar inicial, quanto às praças especiais, que são compostas pelos alunos das escolas militares. Apesar das duas categorias serem objeto do mesmo dispositivo, o STF entendeu que não poderia inserir na súmula a segunda hipótese, tendo em vista que todos os precedentes haviam tratado somente das praças iniciais.

Em outras súmulas, a diversidade de circunstâncias dos precedentes põe em dúvida a correção do enunciado, o que deve ser objeto de máximo cuidado quando se trata de decisões que restringem direitos. Na Súmula Vinculante $n^{0} 5^{12}$, o principal precedente, $\mathrm{RE} \mathrm{n}^{\circ}$ 434.059, considerou que, no processo administrativo disciplinar, as garantias da ampla defesa e o contraditório são atendidas pela própria manifestação

\footnotetext{
${ }^{8}$ Enunciado $\mathrm{n}^{\circ}$ 21: “O trabalhador faz jus ao crédito integral, sem parcelamento, e ao levantamento, nos casos previstos em Lei, das verbas relativas aos expurgos de índices inflacionários de janeiro de 1989 (42,72\%) e abril de 1990 (44,80\%) sobre os saldos das contas de FGTS, ainda que tenha aderido ao acordo previsto na Lei Complementar $n^{\circ} 110 / 2001$, deduzidas as parcelas porventura já recebidas”.

${ }^{9} \mathrm{SV}^{\circ}{ }^{\circ}$ 3: "Nos processos perante o Tribunal de Contas da União asseguram-se o contraditório e a ampla defesa quando da decisão puder resultar anulação ou revogação de ato administrativo que beneficie o interessado, excetuada a apreciação da legalidade do ato de concessão inicial de aposentadoria, reforma e pensão”.

${ }^{10}$ De acordo com o art. 71, III, da Constituição da República, compete ao Tribunal de Contas da União, "apreciar, para fins de registro, a legalidade dos atos de admissão de pessoal, a qualquer título, na administração direta e indireta, incluídas as fundações instituídas e mantidas pelo Poder Público, excetuadas as nomeações para cargo de provimento em comissão, bem como a das concessões de aposentadorias, reformas e pensões, ressalvadas as melhorias posteriores que não alterem o fundamento legal do ato concessório”.

${ }^{11} \mathrm{SV} \mathrm{n}^{\circ}$ 6: "Não viola a Constituição o estabelecimento de remuneração inferior ao salário mínimo para as praças prestadoras de serviço militar inicial”.

${ }^{12} \mathrm{SV} \mathrm{n}^{\circ}$ 5: "A falta de defesa técnica por advogado no processo administrativo disciplinar não ofende a Constituição”.
} 
do servidor, qualificando a defesa técnica como mera faculdade estabelecida em lei. ${ }^{13}$ Apesar disso, a Min. Cármen Lúcia reconheceu a existência de hipóteses em que o servidor não está apto para fazer sua defesa, tendo em vista a complexidade da matéria, e o Min. Cesar Peluso admitiu que o Estado está obrigado a garantir a assistência jurídica caso o interessado não tenha condições de provê-la.

Neste caso, os próprios Ministros reconhecem que não havia decisões reiteradas sobre a matéria, o que os leva a discutir sobre a possibilidade de aprovação da súmula vinculante. Ao final, prevaleceu a idéia de que, em razão da existência de enunciado em sentido contrário do Superior Tribunal de Justiça ${ }^{14}$, o STF deveria sumular seu entendimento para impedir a multiplicação de recursos sobre o tema, atendendo à segurança jurídica. Essa desatenção aos precedentes, contudo, leva a listar entre eles casos que não trataram de processo administrativo disciplinar, como o AI-AgR n 207.197, sobre ausência de advogado no julgamento de recurso administrativo fiscal, e o MS n ${ }^{\circ}$ 24.961, que trata de Tomada de Conta Especial pelo Tribunal de Contas da União. O único precedente citado que se refere à defesa em PAD é o RE-AgR n 244.027, em que a decisão mantida pelo STF não envolvia uma sanção grave como a demissão, mas apenas o desligamento de um policial militar do Curso de Formação de Oficiais.

Observa-se, assim, que o STF não verifica a adequação dos precedentes citados na decisão que leva à aprovação da súmula. O fundamento de que o contraditório e da ampla defesa no âmbito do processo administrativo não obrigam à atuação do advogado consta, efetivamente, em todos os precedentes, mas sua descontextualização faz com que o STF edite uma súmula cujo enunciado dificulta a identificação de situações em que, como seus próprios membros reconhecem, a defesa técnica pode ser constitucionalmente exigível.

Problema semelhante com o uso dos precedentes verifica-se na Súmula Vinculante $n^{\circ} 9 .^{15}$ Nesse enunciado, o STF declara a recepção do dispositivo da Lei de Execução Penal que pune o condenado que praticar falta grave com a perda do direito ao tempo remido, mas, em alguns precedentes, os Ministros consideram que a desproporcionalidade na aplicação da norma poderia afastá-la. ${ }^{16}$

No caso concreto, portanto, a súmula não pode se sobrepor ao princípio da proporcionalidade da sanção, devendo o juiz levar em conta o tempo de trabalho já contado pelo preso e o tipo de infração cometida, pois a lei qualifica como "falta grave" condutas tão distintas quanto "fugir" (art. 50, II) e a inobservância pelo preso do dever de "respeito a qualquer pessoa com quem deva relacionar-se" (art. 50, VI, c/c art. 39, II). No decorrer dos debates sobre a redação do enunciado, isso foi admitido pelos próprios membros do STF, pela voz do Min. Carlos Britto: "Nós não estamos aqui fechando nenhum compromisso com o conceito de falta grave".

\footnotetext{
13 “É assegurado ao servidor o direito de acompanhar o processo pessoalmente ou por intermédio de procurador, arrolar e reinquirir testemunhas, produzir provas e contraprovas e formular quesitos, quando se tratar de prova pericial” (Lei $n^{\circ} 8.112 / 90$, art. 156).

${ }^{14}$ Súmula ${ }^{\circ} 343$ : "É obrigatória a presença de advogado em todas as fases do processo administrativo disciplinar"

${ }^{15}$ SV n ${ }^{\circ}$ 9: “O disposto no artigo 127 da Lei n ${ }^{\circ}$ 7.210/1984 (Lei de Execução Penal) foi recebido pela ordem constitucional vigente, e não se lhe aplica o limite temporal previsto no caput do artigo 58”.

${ }^{16}$ Cf. HC n ${ }^{\circ} 92.791$ e RE n ${ }^{\circ} 452.994$.
} 
Pouco tempo após a edição da súmula, o STF teve que realizar esse distinguishing, deixando de aplicá-la no $\mathrm{HC} \mathrm{n}^{\circ}$ 94.701, em que o desconto de dias remidos em razão do preso não ter respondido à conferência na penitenciária foi considerado desproporcional.

As duas súmulas de maior impacto, dentre as editadas até aqui, também colocam em dúvida o cumprimento, pelo STF, dos comandos constitucionais.

$\mathrm{Na}$ Súmula Vinculante $\mathrm{n}^{0} 11^{17}$, os precedentes relacionados são bastante diversos. O RHC n 56.465 foi julgado em 5 de setembro de 1978, sendo, portanto, anterior à Constituição. Neste caso, o uso de algemas ocorreu durante audiência para colher depoimento de testemunha, e foi considerado justificado, como se vê na ementa: "Não constitui constrangimento ilegal o uso de algemas por parte do acusado, durante a instrução criminal, se necessário à ordem dos trabalhos e à segurança das testemunhas e como meio de prevenir a fuga do preso"

O segundo precedente citado, $\mathrm{HC}^{\circ}{ }^{\circ}$ 71.195, foi julgado em 25 de outubro de 1994. Nele, o réu havia permanecido algemado em plenário durante o tribunal do júri, mas o STF também julgou a medida justificada, tendo em vista a necessidade de garantir a segurança do juiz presidente e do promotor de justiça, que haviam sido ameaçados pelo réu. Destacou-se no caso, ainda, que o advogado de defesa concordara com a medida. A ementa, redigida com nítida inspiração no precedente anterior, citado no voto do Relator, averba: "O uso de algemas durante o julgamento não constitui constrangimento ilegal se essencial à ordem dos trabalhos e à segurança dos presentes”.

O terceiro precedente é o $\mathrm{HC} \mathrm{n}^{0}$ 89.429, julgado em 22 de agosto de 2006. Nesse, ao contrário dos demais, o STF defere o pedido de habeas corpus, para que o paciente não fosse algemado durante os procedimentos da instrução criminal, estabelecendo que: “O uso ilegítimo de algemas não é arbitrário, sendo de natureza excepcional, a ser adotado nos casos e com as finalidades de impedir, prevenir ou dificultar a fuga ou reação indevida do preso, desde que haja fundada suspeita ou justificado receio de que tanto venha a ocorrer, e para evitar agressão do preso contra os próprios policiais, contra terceiros ou contra si mesmo”.

O último precedente, a partir do qual foi proposta a edição da súmula, é o HC $n^{\circ}$ 91.952, julgado em 7 de agosto de 2008. Nele, é anulado júri em que o réu permaneceu algemado sem que ficasse demonstrada sua periculosidade ou risco de fuga. Dentre os fundamentos da decisão, destacam-se os princípios constitucionais da presunção de inocência e do respeito à integridade física e moral do preso, mas também o fato de que o STF considerou insatisfatória as justificativas apresentadas pelo juiz, de que havia somente dois policiais civis encarregados da segurança do plenário e que o réu havia comparecido algemado a todas as audiências. Além disso, o Min. Marco Aurélio, Relator, destaca as circunstâncias peculiares ao Tribunal do Júri: “O julgamento no Júri é procedido por pessoas leigas, que tiram as mais variadas ilações do quadro verificado. A permanência do réu algemado indica, à primeira

\footnotetext{
${ }^{17} \mathrm{SV} \mathrm{n}^{0}$ 11: "Só é lícito o uso de algemas em casos de resistência e de fundado receio de fuga ou de perigo à integridade física própria ou alheia, por parte do preso ou de terceiros, justificada a excepcionalidade por escrito, sob pena de responsabilidade disciplinar, civil e penal do agente ou da autoridade e de nulidade da prisão ou do ato processual a que se refere, sem prejuízo da responsabilidade civil do Estado”.
} 
visão, cuidar-se de criminoso da mais alta periculosidade, desequilibrando o julgamento a ocorrer, ficando os jurados sugestionados".

Observa-se, no julgado, que esse conjunto de elementos relacionados ao Júri são inseparáveis da conclusão tomada pelo $\mathrm{STF}^{18}$, assim como, no precedente anterior, o Tribunal concede o habeas corpus porque não havia evidências da necessidade do uso de algemas. Conquanto seja correto afirmar que, nesse julgamento, o STF firma a tese da excepcionalidade do uso das algemas, ao mesmo tempo considera que sua utilização deveria ser objeto de análise em cada caso, mesmo no âmbito do Tribunal do Júri.

A dificuldade de editar uma súmula vinculante sem observar a existência de reiteradas decisões sobre questão idêntica transparece nos debates da sessão que deliberou sobre seu enunciado. Em vez de clarificar as circunstâncias da excepcionalidade do uso das algemas, contribuindo para definir os parâmetros de julgamento dos casos futuros, os Ministros se detêm na tentativa de explicitar as conseqüências do descumprimento da súmula. A razão disso pode ser encontrada nos próprios debates: tal como nos dois últimos precedentes citados, a principal preocupação do STF é com a exposição aos meios de comunicação do preso algemado.

Não cabe dúvida sobre a importância de debater as garantias de um direito fundamental, tal como a integridade física e moral do preso; questionável, no entanto, é o meio utilizado pelo STF nessa discussão. Assim, apesar dos esforços em discutir o tipo de responsabilização do agente e as conseqüências do uso irregular de algemas, o próprio STF reconhece as dificuldades de aplicação da súmula. Como observado pelo Procurador-Geral da República, os precedentes versaram sobre situações (audiência e tribunal do júri) em que há uma preparação dos agentes públicos para garantir a segurança do réu e dos demais participantes desses atos, o que não ocorre no cumprimento de mandado de prisão, situação "potencialmente conflituosa". A esses comentários, responde o Min. Peluso com uma observação que sintetiza as dificuldades: “(...) só vamos reconhecer ilícito, quando este fique claro, como caso em que se aplicam as algemas sem nenhum risco, com o só propósito de expor o preso à execração pública, ou de lhe impor, longe do público, constrangimento absolutamente desnecessário. Nos casos de dúvida, a interpretação tem sempre de ser a favor do agente do Estado, porque realmente é situação perigosa a de conduzir preso." (grifo nosso).

Dessa maneira, a SV $\mathrm{n}^{\mathrm{o}} 11$ pouco acrescenta ao ordenamento jurídico. ${ }^{19}$ Apesar de sua extensa redação, o próprio STF reconhece que a autoridade policial ou

\footnotetext{
${ }^{18}$ Isso não escapa ao próprio Tribunal, como exemplifica o Min. Carlos Britto: "Estamos, aqui, julgando, exclusivamente, o uso de algemas no Plenário do Tribunal do Júri. Este é o locus físico da nossa cognição e, por conseqüência, do equacionamento jurídico que nos cabe fazer”.

${ }^{19}$ Vejam-se as seguintes disposições do Código de Processo Penal, também lembradas pelos Ministros nos precedentes: “Art. 284 - Não será permitido o emprego de força, salvo a indispensável no caso de resistência ou de tentativa de fuga do preso”; “Art. 292 - Se houver, ainda que por parte de terceiros, resistência à prisão em flagrante ou à determinada por autoridade competente, o executor e as pessoas que o auxiliarem poderão usar dos meios necessários para defender-se ou para vencer a resistência, do que tudo se lavrará auto subscrito também por duas testemunhas.”

Em relação ao Tribunal do Júri, a nova redação do $\S 3^{\circ}$ do art. 474 do CPP também lida com a questão:
} 
judiciária permanece com um amplo espectro de deliberação, o que torna a súmula muito mais persuasiva, tal como as súmulas comuns, do que vinculante. Esses problemas talvez fossem evitados caso o STF, em vez de apenas trabalhar no nível de abstração que ao final prevaleceu, redigindo hipóteses genéricas sobre o uso de algemas, aproveitasse a riqueza dos casos para a elaboração da súmula, concentrando-se nas duas situações analisadas, que envolveram o tribunal do júri e a realização de audiências, para concretizar as hipóteses. O problema do enunciado da $\mathrm{SV} \mathrm{n}^{\circ} 11$, portanto, não está na vagueza de termos como "fundado receio" ou "perigo", mas em sua descontextualização, que prejudica a identificação dos casos aos quais a súmula se aplica. Prestar-se-ia melhor serviço à proteção dos direitos fundamentais se o STF desse um passo na construção jurisprudencial, identificando situações concretas de violação dos direitos fundamentais. ${ }^{20}$

Em conseqüência, ao abstrair as circunstâncias dos casos que originaram os precedentes, o STF não logra produzir um texto normativo com densidade suficiente para regular a matéria. Mas, como sabemos, um dos efeitos das súmulas vinculantes é a possibilidade de ajuizamento de reclamação junto ao STF. Pergunta-se: tornar-se-á o STF órgão de revisão da constitucionalidade do uso de algemas em todo o país? ${ }^{21}$

O distanciamento dos precedentes torna-se mais nítido na $\mathrm{SV} \mathrm{n}^{0} 13^{22}$ cuja rapidez com que foi produzida impediu o STF de analisar corretamente as circunstâncias dos casos. Destacam-se aqui várias diferenças.

Na ADIn no 1.521, julgada em 12 de março de 1997, em sede cautelar, foi mantida a eficácia de diversos dispositivos da Constituição do Estado do Rio Grande do Sul, em que a proibição de nomeação atingia somente o segundo grau de parentesco.

No MS n 23.780, julgado em 28 de setembro de 2005, a base da decisão é a

“Não se permitirá o uso de algemas no acusado durante o período em que permanecer no plenário do júri, salvo se absolutamente necessário à ordem dos trabalhos, à segurança das testemunhas ou à garantia da integridade física dos presentes.”

${ }^{20}$ Pode-se comparar essa situação com a generalização feita pela SV n ${ }^{\circ} 4$ ("Salvo nos casos previstos na Constituição, o salário mínimo não pode ser usado como indexador de base de cálculo de vantagem de servidor público ou de empregado, nem ser substituído por decisão judicial”). Nessa súmula, os precedentes trataram, em sua maioria, de adicional de insalubridade, havendo ainda casos envolvendo pensões e decisões judiciais. Apesar dessas diferenças, todas as situações abarcavam servidores públicos e empregados, o que permite considerar a existência de decisões reiteradas. No caso da $S V n^{\circ} 11$, o aspecto comum dos precedentes é o fato de que o cidadão já se encontrava sob a custódia do Estado antes da colocação das algemas para comparecer à audiência e ao tribunal do júri. Esse elemento, articulado no enunciado da súmula, possibilitaria uma base mais adequada para sua aplicação.

${ }^{21}$ No julgamento de várias reclamações apresentadas com base na SV $n^{\circ} 11$, o Tribunal tem considerado suficiente a existência de justificativa por escrito, usando como argumento que não se admite, em sede de reclamação, "qualquer dúvida a respeito das questões de fato" apontadas pela autoridade judicial. Cf. RCLs $\mathrm{n}^{\circ}$ 6.870, 6.564 e 6.963. Como vemos, isso confirma a dificuldade de julgamento de casos concretos a partir da súmula.

${ }^{22} \mathrm{SV} \mathrm{n}^{\circ}$ 13: "A nomeação de cônjuge, companheiro ou parente em linha reta, colateral ou por afinidade, até o terceiro grau, inclusive, da autoridade nomeante ou de servidor da mesma pessoa jurídica investido em cargo de direção, chefia ou assessoramento, para o exercício de cargo em comissão ou de confiança ou, ainda, de função gratificada na administração pública direta e indireta em qualquer dos poderes da União, dos Estados, do Distrito Federal e dos Municípios, compreendido o ajuste mediante designações recíprocas, viola a Constituição Federal”. 
Lei $n^{\circ} 9.421 / 96$, que, em seu art. 10, veda a nomeação até o terceiro grau, mas não trata de nepotismo cruzado, e a Lei $n^{\circ} 8.432 / 92$, art. $44, \S 3^{\circ}$, que trata especificamente de cargos na Justiça do Trabalho.

Deve-se destacar, em ambos os casos, que a existência de lei não exigiu que o STF estabelecesse critérios sobre o nepotismo, mas somente julgasse a adequação dessa legislação à Constituição, reconhecendo a liberdade do legislador para dispor sobre a matéria.

Por fim, no RE nº 579.951, que levou à edição da súmula, o STF decidiu anular ato de nomeação de irmão do Vice-Prefeito para o cargo de motorista. No mesmo acórdão, o STF considerou que a nomeação de agentes políticos não estaria vedada, dentre outras hipóteses discutidas que apontam a necessidade de apreciar o caso concreto, especialmente para aferir a prática de nepotismo cruzado.

Apesar de, rigorosamente, contar com um único precedente, o STF decidiu usar a Resolução $n^{\circ} 7$ do CNJ sobre nepotismo como base da redação da súmula, tendo em vista sua decisão na ADC $n^{0} 12$. Nesse julgado, o STF considerou que a referida resolução "densifica” os princípios constitucionais inscritos no art. 37 (impessoalidade, eficiência, igualdade, moralidade), "não havendo antinomia de conteúdos na comparação dos comandos que se veiculam pelos dois modelos normativos: o constitucional e o infra-constitucional” (Min. Carlos Britto). Assim, as restrições às nomeações de parentes no Poder Judiciário seriam compatíveis com as restrições impostas pela Constituição, donde se pode concluir que o Executivo e o Legislativo também estão sujeitos aos mesmos limites.

Pode-se argumentar, em defesa da SV $n^{0} 13$, que, tal como no julgamento da ADC $n^{0} 12$, o STF baseou-se em uma aplicação direta dos princípios constitucionais. Contudo, um dos fundamentos mais importantes da decisão da ADC $\mathrm{n}^{\circ} 12$ reconhecia a competência do CNJ para regular a matéria por meio da edição de atos normativos primários, com base no inciso II do $\S 3^{\circ}$ do art. 103-B, que não faz referência à edição de lei para o exercício da competência. Segundo o Relator, Min. Carlos Britto, esse dispositivo outorga competência para o Conselho dispor, primariamente, sobre as matérias lá constantes, por ser uma "forma de prevenir a irrupção de conflitos. O poder de precaver-se ou acautelar-se para minimizar a possibilidade das transgressões em concreto.” Outros Ministros, como Joaquim Barbosa e César Peluso invocaram a tese dos "poderes implícitos" para julgar legítimo o exercício de competência normativa pelo CNJ.

A discussão sobre a competência do CNJ não exauriu, contudo, o debate sobre a constitucionalidade da Res. $\mathrm{n}^{\circ} 7$, pois os Ministros ainda tiveram que enfrentar a questão da adequação dos graus de parentesco estabelecido no ato normativo, especialmente o problema do parentesco por afinidade até o terceiro grau. Esse tipo de dificuldade revela que o conjunto normativo utilizado para o Poder Judiciário não teria, necessariamente, que ser empregado para os demais poderes. Se o entendimento do STF sobre a aplicação direta do art. 37 pode fundamentar sua própria competência para dispor sobre a nomeação de parentes em outros poderes, o exercício dessa competência teria que ser feito a partir da análise das particularidades dos poderes executivo e legislativo, advinda de um conjunto de decisões sobre o tema. 
Como vimos acima, uma dessas particularidades, envolvendo a figura dos agentes políticos, foi reconhecida pelo próprio STF no precedente, ainda que não tenha constado no enunciado da súmula, gerando dúvidas sobre sua aplicação. ${ }^{23}$ Por não se basear em um exame cuidadoso dos casos e diante das óbvias dificuldades de estabelecer uma regra geral para a questão, o STF escolheu usar o termo "pessoa jurídica” no enunciado da súmula, cuja imprecisão não demorou a ser notada. ${ }^{24}$ Assim como no caso anterior, a generalidade do enunciado decorre de uma ausência de compreensão e cuidado com os precedentes.

\section{CONCLUSÃO}

A análise desenvolvida neste trabalho indica vários problemas no cumprimento das exigências constitucionais para edição de súmulas vinculantes. Como vimos, as características dos casos julgados não têm sido sempre analisadas pelo STF, o que leva a uma generalização imprópria dos precedentes, desprovida da contextualização que é necessária para identificar a existência de reiteradas decisões sobre questão idêntica.

Em conseqüência, corre-se o risco de que a súmula vinculante sirva para veicular as preferências do STF sobre o modo como determinadas matérias devem ser reguladas, competência que somente pode ser exercida pelo legislador. Apesar de compartilhar com a lei o caráter de texto normativo, a súmula vinculante está algemada aos precedentes, não cabendo ao STF, no momento de sua edição, ir além do que foi decidido. A interpretação da Constituição que legitima a súmula não se realiza de modo autônomo, mas por meio dos casos julgados.

Sem o devido respeito aos precedentes, amplia-se o risco da discricionariedade na interpretação da súmula pelo próprio STF. Como bem observado por Streck (2008), enunciados escondem o aparecer da singularidade dos casos. Quanto mais

\footnotetext{
${ }^{23}$ Na RCL no 6.650, o STF suspendeu decisão judicial que anulava nomeação de irmão do Governador do Estado para o cargo de secretário estadual, reafirmando que essa situação não está vedada pela SV $\mathrm{n}^{\circ} 13$.

${ }^{24}$ Uma notícia divulgada na página do STF, em 28 de novembro de 2008, nos serve de exemplo: "PGR pede definições precisas sobre o que é nepotismo. A Súmula Vinculante $\mathrm{n}^{\circ} 13$, aprovada em agosto deste ano pelo Plenário do Supremo Tribunal Federal (STF) para tentar banir do cenário brasileiro o nepotismo, tem causado controvérsias. Isso porque o verbete, com poder normativo, tem recebido interpretação divergente e aplicação diferenciada no país, afirma o procurador-geral da República, Antonio Fernando Souza. Como compete à PGR atuar no sentido de combater o desrespeito a norma, "é fundamental que o Ministério Público tenha conhecimento dos parâmetros precisos de sua compreensão para que possa exercer com segurança as suas atribuições”. Com esse argumento, Antonio Fernando pede à Corte que defina os precisos contornos do que é nepotismo, para unificar sua aplicação e acabar com as dúvidas que têm surgido. O pedido foi feito nos autos da Reclamação (RCL) 6838, ajuizada na Corte pela própria PGR contra o Ato $n^{\circ} 7$ da Comissão Diretora do Senado Federal. Como exemplo, Antonio Fernando cita confusões envolvendo as funções de confiança (que devem ser exercidas exclusivamente por servidores concursados) e cargos em comissão (a serem ocupados preferencialmente por servidores de carreira). Outra dúvida relatada pelo procurador surgiu a partir do entendimento que se tem dado à expressão "mesma pessoa jurídica” como ente federal em sua totalidade (União, Estado, Distrito Federal e municípios). Isso tem gerado assimetrias "a alcançar situações que substancialmente não configuram nepotismo”, frisa o procurador-geral. O vínculo conjugal ou parentesco com membro de poder ou autoridade já aposentados é outra questão a ser resolvida, bem como as situações licitamente constituídas e estabelecidas antes da posse da autoridade e o casamento subseqüente. São múltiplas as situações que podem provocar dúvidas, alega Antonio Fernando. O esclarecimento desses pontos contribuiria de modo significativo "para aprimorar a concretização dos comandos nela inseridos’, concluiu.”
} 
genérico for o enunciado, portanto, maiores serão as dificuldades de manter o vínculo da súmula com os casos anteriores, o que condiciona sua correta interpretação. Como a formação de significados de significantes depende de uma série de circunstâncias, a expressão adequada dos fundamentos dos precedentes no enunciado das súmulas pode ajudar ou não esse processo.

Resultando de um conjunto de decisões judiciais anteriores, as súmulas se inserem em uma cadeia de interpretações, cujos marcos são os precedentes. Considerando esse caráter, a súmula tanto deve se ajustar às decisões passadas, guardando coerência com as circunstâncias dos casos e o fundamento de suas decisões, quanto justificar sua vinculatividade como a solução correta para os casos futuros. ${ }^{25}$ Essa operação requer, como já demonstrado, que o STF desenvolva um juízo de igualdade, fundamentando sua conclusão de que devem ser privilegiadas as similitudes dos casos e afastadas suas diferenças. A contribuição das súmulas, portanto, não está simplesmente na reafirmação dos princípios constitucionais, mas em sua concretização diante de situações específicas.

Por essa razão, deve-se evitar que o enunciado das súmulas se afaste do processo hermenêutico que conduziu os precedentes, apresentando-se, ao contrário, como um momento de interpretação de casos similares, sujeita à revisão crítica de seus fundamentos perante as circunstâncias dos casos futuros. Sem isso, obstrui-se o processo de identificação, em cada caso, da decisão correta, isto é, da solução que está de acordo com o conjunto normativo.

Não é difícil identificar os problemas que tal prática gera para a proteção dos direitos fundamentais. Nessa situação, a súmula vinculante se aproxima das decisões que declaram a constitucionalidade da lei ou realizam interpretação conforme à Constituição, pretendendo estabelecer um comando vinculante para a totalidade de casos a serem decididos com base naquela lei. Contudo, tal pretensão é vã, pois não é possível antever todos os casos aos quais a lei irá se aplicar nem as eventuais situações inconstitucionais decorrentes dessa aplicação, por violarem direitos fundamentais.

Como já defendemos anteriormente (MAUÉS; FONSECA; RÊGO, 2006), as súmulas vinculantes podem ser um instrumento útil para impedir a aplicação de lei julgada inconstitucional na via difusa ${ }^{26}$ e para reforçar o direito ao tratamento igual em determinadas situações. ${ }^{27}$ Para cumprir com esse objetivo, contudo, é indispensável que o STF se atenha aos comandos constitucionais, pois a legitimidade do uso do precedente se baseia no direito à igualdade: a norma do caso, formulada na ratio decidendi, generaliza-se quando as circunstâncias de outro caso o exigem para que seja dado um tratamento igual. Não é constitucionalmente admissível que o STF fuja às interpretações desenvolvidas nos precedentes para formular novas interpretações para casos que não foram tratados.

${ }^{25}$ Para os conceitos de ajuste (fit) e justificação (justification), ver Dworkin (1991, cap. 7).

${ }^{26}$ Por exemplo, a SV $n^{\circ}$ 8: "São inconstitucionais o parágrafo único do artigo $5^{\circ}$ do Decreto-Lei $\mathrm{n}^{\circ}$ 1.569/1977 e os artigos 45 e 46 da Lei no 8.212/1991, que tratam de prescrição e decadência de crédito tributário".

${ }^{27}$ Tal é o caso da SV ${ }^{\circ}$ 3, que garante o contraditório e ampla defesa em um conjunto de processos perante o TCU. 
Portanto, a contribuição das súmulas vinculantes para a proteção dos direitos fundamentais não advém da produção de um enunciado semelhante à lei, mas da cristalização de interpretações de situações concretas, as quais devem se encaixar na cadeia de interpretações da Constituição como um novo elo protetor dos direitos fundamentais, mantendo a justiça constitucional aberta a novas demandas em nosso país.

\section{REFERÊNCIAS BIBLIOGRÁFICAS}

DWORKIN, Ronald. Law's Empire. Londres: Fontana Press, 1991.

FAVOREU, Louis. Modèle Americain et Modèle Européen de Justice Constitutionnelle. Annuaire international de justice constitutionnelle, vol. IV, 1988.

HAMILTON, A.; MADISON, J.; JAY, J. O Federalista. Brasília: UnB, 1984.

KELSEN, Hans. Jurisdição Constitucional. São Paulo: Martins Fontes, 2003.

LLORENTE, Francisco Rubio. La jurisdicción constitucional como forma de creación del Derecho. In: La forma del poder. Estudios sobre la Constitución. Madri: Centro de Estudios Constitucionales, 1997.

MANCUSO, Rodolfo de Camargo. Súmula vinculante e a EC n 45/2004. In: WAMBIER, Teresa Arruda Alvim et alli (Coords.) Reforma do Judiciário. Primeiros ensaios críticos sobre a EC $n^{\circ}$ 45/2004. São Paulo: Revista dos Tribunais, 2005.

MAUÉS, Antonio Moreira; FONSECA, Mônica Maciel Soares; RÊGO, Lorena de Paula da Silva. Súmula Vinculante e Direito à Igualdade. Revista do Instituto de Pesquisas e Estudos, nº 46, 2006.

MAUÉS, Antonio Moreira. Ensaio sobre a Harmonização da Jurisprudência Constitucional. In: OLIVEIRA NETO, Francisco José Rodrigues; COUTINHO, Jacinto Nelson de Miranda; MEZZAROBA, Orides; BRANDÃO, Paulo de Tarso (Orgs.). Constituição e Estado Social. São Paulo: Revista dos Tribunais, 2008.

MEDINA, José Miguel Garcia; WAMBIER, Luiz Rodrigues; WAMBIER, Teresa Arruda Alvim. Repercussão geral e súmula vinculante - Relevantes novidades trazidas pela EC $\mathrm{n}^{\circ}$ 45/2004. In: WAMBIER, Teresa Arruda Alvim et alli (Coords.) Reforma do Judiciário. Primeiros ensaios críticos sobre a EC $n^{\circ}$ 45/2004. São Paulo: Revista dos Tribunais, 2005.

MIRANDA, Tássia Baia. Stare Decisis e a Aplicação do Precedente no Sistema NorteAmericano. Revista da AJURIS, n 106, 2007.

PEGORARO, Lucio. La justicia constitucional. Una perspectiva comparada. Madrid: Dykinson, 2004.

SCAFF, Fernando Facury; MAUÉS, Antonio G. Moreira. Justiça Constitucional e Tributação. São Paulo: Dialética, 2005.

STRECK, Lenio Luis. As Súmulas Vinculantes em Face da Hermenêutica Filosófica e da Jurisdição Constitucional. In: PRADO, Geraldo Luiz Mascarenhas (Coord.). Acesso à Justiça e Efetividade do Processo. Rio de Janeiro: Lumen Juris, 2005.

STRECK, Lenio Luiz. Súmulas, Vaguezas e Ambigüidades: Necessitamos de uma "Teoria Geral dos Precedentes”? Direitos Fundamentais e Justiça, nº 5, 2008. 